\title{
Increasing Students' Intercultural Awareness Using Film as the Media in the EFL Classroom
}

\author{
Yeni Dyah Nur Kartikasari $1^{1 a^{*}}$, Pratiwi Retnaningdyah ${ }^{1, b}$, and Ali Mustofa ${ }^{1, c}$ \\ ${ }^{1}$ Faculty of Language and Literature Education, State University of Surabaya, Surabaya, East Java, Indonesia \\ a yeni.17070835059@mhs.unesa.ac.id; b pratiwiretnaningdyah@unesa.ac.id ; c alimustofa@unesa.ac.id \\ *Corresponding Author \\ Whatsapp Number [ +6283857708706]
}

How to Cite : Kartikasari, Y., D., N., Retnaningdyah, P., Mustofa, A. (2019). Increasing Students' Intercultural Awareness Using Film as the Media in the EFL Classroom. International Journal for Educational and Vocational Studies, 1 (7), 681-690

\section{ARTICLE HISTORY}

Received: 11 August 2019

Revised: 10 September 2019

Accepted: 25 October 2019

\section{KEYWORDS}

Intercultural Awareness; Students' Intercultural Awareness; Cultural Content Category; EFL Classroom:

\begin{abstract}
The study was aimed to obtain information regarding to the teacher's strategy and students' aspects of Intercultural Awareness (ICA) perceived from CCC through film. It was qualitative study and data of the study were taken from documentations which consisted of observation sheets, field notes, and students' journal writing with guided questions in three phases: before, during and after viewing the film. Based on data analysis, the result shows that there were four categories in the strategies of ICA the teacher developed through film in the EFL classroom. The teacher also tended to apply the QAR strategies as well as it aimed at improving students' reading comprehension before, during and after watching the film which showed six steps. The six steps were by visualizing to the information to students' own experience, recalling students' past experiences, clarifying to students' behavior towards different cultures from their own, locating the information from the film, imagining to the position of the characters in the film, and summarizing the film to the positive and negative sides. Another finding was found that from twenty-one aspects, there was 'respect to others' as major key of all aspects of ICA emerged. The two findings contributed much for intercultural study.
\end{abstract}

This is an open access article under the CC-BY-SA license.

\section{INTRODUCTION}

It has been convinced that the need of communication among other countries to be meaningful and knowledgeable culturally the past twenty years is undoubted. It is well-understood that people who live multilingual societies are socially responsible and knowledgeable (P. M. Ribeiro, 2016). And even English has function as intercultural communication language for those people who do not speak it as native speakers (Kusumaningputri \& Widodo, 2018; Marzuki, 2019).

As a matter of fact, cultural awareness has been generally found in the textbooks of English as the part of learning. This phenomenon shows the importance of understanding the way people communicate the language differently with others in different settings is no exception (Halliday \& Hasan, 1989). Besides, teachers are found the difficulties to control the students in their unexpected learning due to their lack of cultural content knowledge. they only concern on their grammar and text books. But not for intercultural communication (Kiss \& Weninger, 2017).
And recently, there have been studies about the need of media to promote intercultural understanding. (Chao, 2013; Kiss \& Weninger, 2017; P. M. Ribeiro, 2016; Tanghe, 2016), for instance, have claimed that many educators have conducted the use of media like digital stories, foreign films, and visual texts to promote intercultural understanding. Interestingly, Chao (2013) found that most of the students who were majoring English at a technological university in Hsinchu, Taiwan were highly motivated to participate in the study based-foreign film as the visual text in learning intercultural communicative competence. Therefore, the use of film as media to teach culture is recommended as it has benefits for the students to study the language in the EFL classroom. By knowing the content of the film, the foreign language learners can draw the social situation for gaining cultural knowledge, the language practice, and intercultural study (Bueno, 2009; Pegrum, 2008; Roell, 2010; Fitriani et al., 2019). However, the use of film as media in developing learners' intercultural awareness has been very little and well-implemented for business 
communication students of universities in Asia curricula (Briam, 2010; Cardon, 2010; Mallinger \& Rossy, 2003), but little evidence for high school students.

Film as audio and visual media, however, brings the stereotype to the audiences. The stereotypes are sometimes not only constructive but also hurtful conscious and unconsciously. Viewers tend to take sides to the similar cultures with their own when they find differences from other cultures (Cardon, 2010).

In respect with the intercultural awareness aspects, there is possibly 'identity' embroils the intercultural communication and the factors behind it. Moreover, the intercultural meeting creates the potency of anxiety, misunderstandings and even problems (Galante, 2015; Samovar, Porter, Mcdaniel, \& Roy, 2012). Scollon (2001) states that conscious control and awareness of variety cultures involve human activities in the communicative activity. It can be said that students are conscious to compare others cultures with their own.

To overall the gaps based on the previous studies, the study which has not been implemented is the study about intercultural context for high school level since pedagogical use of film is well-succeeded for intercultural business communication of university students (Briam, 2010; Cardon, 2010; Mallinger \& Rossy, 2003). Furthermore, the study of aspects of ICA through film has not been implemented for high school students as (Baranauskiene, 2012) conducts the study using text for university level.

\section{METHODS}

\subsection{The Concept of Culture}

The importance of knowing the culture and language is undeniable. The role of culture is explained to make the language learners prepare for the intercultural communication (Byram, 1997). And culture is pragmatically related to the language that is being learned (Byram \& Phipps, 2003). To give the closely intertwined nature between culture and language, it is said not to be easy to teach language without applying an acknowledgment of the cultural context (Baker, 2012).

Sercue (2005) stated that culture carries out a person who has a number of cultural competencies and characteristics, is definitely able to cope with intercultural experiences. Otherwise, the experience of otherness in a range of ways creates a potential for questioning the taken-for-granted in one's own self and environment (Alfred, Byram, \& Fleming, 2003). This integration is reflected on (Byram, 1997), the overview of communicative competence in which he suggests pedagogical implementations with the model of Intercultural Communicative Competence (ICC). The ICC models comprise five "knowledge" or "saviors:" Attitudes relativizing self, valuing other (savoir etre); Education: political education, critical cultural awareness (savoir 's engager); Skills: discover and/or interact (savoir aprendre/faire); Knowledge of self and other; of interaction: individual and societal (savoir etre) and Skills interpret and relate (savoir comprehend). From the five knowledge, language learners are able to avoid misunderstandings to other cultures which tend to different with their own cultures.

\subsection{The Cultural Content Category (CCC) to Boost Students' Intercultural Awareness (ICA)}

The importance of increasing knowledge of other foreign cultures in the EFL classroom, making various attempts to communicate the language. Some communications are valued by the use of the body language, for example, in a purpose of contact, closeness, and gesticulation. This brings up the key of cultural dimension in Intercultural Communicative Competence (ICC) for instance, empathy, curiosity, critical awareness, cultural relativism, and cultural identity (Byram, 1997). Therefore, ICC extends the myriad focuses on intercultural discussion on identity to integrate it with dimension with educational projects in the English classroom (Galante, 2015), stereotyping across culture (Cardon, 2010), from cultural awareness to intercultural awareness (Baker, 2012), and cultural learning in the EFL classroom (Kiss \& Weninger, 2017).

From the above explanation, the followings are the Content Cultural Category (CCC) which can be used in analyzing the culture interrelationships used with these categories: social identity, beliefs and behaviors, socio and political institutions, national history, national geography, formality, and politeness (Byram, 1997). The all elements in the CCC have been used by (Baranauskiene, 2012), another previous researcher in his article. However, the study does not focus on 'formality' and 'politeness' as the limitation of the study.

The first concept is social identity. It is meant to individuals' membership knowledge of a social group as self-concept with the value and emotional membership. Second, beliefs and behaviors make up meanings with the group practices that view learners do not notice these as 'fixed' or objective, but altering and deliberating overtimes by groups or members. Another concept is the relational knowledge about other countries and the identities brought to an interaction by an interlocutor from another country, for instance, socio-political institutions, knowledge of the history of foreign countries or their national history, and geography. Furthermore, the intercultural speaker also understands the formality levels in the language and behaviors of interaction, behavior convention and taboos, and beliefs in daily situations. The above all subjects are the Cultural Content Categories (CCC) in studying Intercultural Awareness (ICA).

\subsection{ICA Education in the EFL Classroom}

In education, Byram (1997) emphasizes the needs of ICA to learn EFL. Teaching foreign language describes a teacher who designs a competence building process. To develop ICA, the ongoing process can be seen in the classroom activities that the researchers do observation, analysis, and 
comparison. The attempts to develop ICA, for instance, first, raising the awareness of the language and culture; second, guiding learners to do unbiased comparison, and presenting as many as different aspects of ICA. From those, different points of view related to language and culture can be identified, interceded, and acceded.

Some previous studies found that some intercultural skills like being curiosity, willingness, and openness (Tarp, 2017) on cultural knowledge, aware of their own attitudes and beliefs (Byram, Gribkova, \& Starkey, 2002) have been visualized by the students. From those, the ICA can be manifested as it has advantages for students. Samovar et al (2012) mentions that the products of culture consist of the distinguishes in values, beliefs, attitudes, behaviors, and communication practices. By this, the term 'ICA' emerges foreign language education reflects the learning processes shown by the various levels at which culture affects communication.

\subsection{Student's Journal Writings of Culture}

The four pillars of education, learning to know, learning to do, learning to live together and learning to be (Delors et al., 1996), convinces the investigation of students' ICA through journal writings of culture in the study. In the intercultural classroom communication, it is supposed to make important mutual understanding and respect toward different ethnic, cultural, religious, heritage, and language background (Cavalli, Coste, Alexandru, \& Van de Ven, 2009).

For the above reasons, journal writing is recommended to be an effective method for non-native speakers and teachers to use for teaching writing. Furthermore, Journal writing is writing regularly in a writing log about daily experiences, and recording observation and thoughts, reflections, and perceptions on different topics. it is more concerned and systematic to develop students' ideas to write a specific topic or event (Hashemi \& Amerian, 2011). Besides, Breeze (2017) also convinces that the journal writing has given benefits for students. They give and accept real feedback on their writing. They are also courageous to get to know what they are writing for as their peers and so are the teachers.

Some researchers have claimed that teachers have successfully implemented the use of journal writing in their EFL classroom. Writing composition instructions by the students, makes teachers get their best teaching experiences (Collins, 2001; Jago, Shea, \& Scanlon, 2011).

\subsection{The Use of Film to Boost ICA in the EFL Classroom}

Film is said as the 'visual' and 'audio' media. It is not only the activity of viewing but also visual literate through words and statements as films acted as textbooks (Hekmati, Ghajar, \& Navidinia, 2018). Teaching the language and intercultural competence using textbook material is unsuitable and insufficient, whereas a real sense of the target culture is referred to the existence of film (Truong \& Tran, 2014). Whereas Sturm (2012) states that film is the art form to encourage the viewers to respond to their intellectual and emotion.

Moreover, some fundamental roles for using film in the EFL classroom are believed to be a good point of achieving new intercultural knowledge. First, Truong \& Tran (2014) mention that film simply shows simply shown an increased interest to engage with and perform in an appropriate intercultural attitude in order to build up their characters. Second, film in the target language is viewed as an efficient and effective way to achieve the target cultures (Sturm, 2012). Third, Aitken (2012) adds that film provides real situations and carries out certain cultural aspects of life such as ways of socializing and sharing traditions with others.

From this, it is challenging for language teachers who prioritize professionalism to have an effort to encourage students to open their mind to other cultures and stimulate them to ask the question rather than persuade them to summarize or use stereotypes to easily answer. By this research project, the film could be the right tool to accommodate learning intercultural awareness.

\section{RESULTS AND DISCUSSION}

\subsection{Research Design}

This study used qualitative research design proposed by (Ary, Jacobs, Sorensen, \& Razavieh, 2010) as it was in natural setting. Here, the school where the study conducted, found the cultural awareness in part of the textbook for high school. This made the study run naturally.

In addition, since this present study has dealt notably with the students' sensitivity of intercultural awareness at a certain film, there were some activities held by the teacher to be observed. It involved students' intercultural experience through film, and after that, writing their feedback as their journal writing with the guided questions after viewing it. The study was also a case study for it concerned a single unit to produce an in-depth description that was rich and holistic.

\subsection{Subject and Setting of the Study}

The subject was the tenth-grade high school students in Surabaya, East Java, Indonesia which consisted of twenty-two female and fourteen male students in a classroom setting. There were thirty-six students totally involving in the study. Due to the existence of the textbooks of English, which put cultural awareness in certain topics provided and students were in their freshman year, it was considered to be natural situation to conduct the study.

\subsection{Data and Source of Data}

In regarding to data based on Ary et al., (2010), they might be collected from written records, for examples, diaries, journals, letters, blogs, created artifacts, e-mail exchanges, memos, photographs, memory boxes, audio recordings, story writing, or other personal, family, or social artifacts. In the study, the data were taken from the notes about the 
analysis of teacher's activity, students' activity, and media used in teaching and learning process for Research Question (RQ 1) and Words, phrases, terms and written responses or statements in the journal writing for RQ 2. To make the data and source od the data were clear in the study, here was given the table below. See table 1 .

Table 1. Research Question (RQ1)

\begin{tabular}{|c|c|c|}
\hline Data & Source of the Data & $\begin{array}{c}\text { Research } \\
\text { Question (RQ) }\end{array}$ \\
\hline $\begin{array}{l}\text { The notes about } \\
\text { the analysis of } \\
\text { teacher's activity, } \\
\text { students' activity, } \\
\text { and media used in } \\
\text { teaching and } \\
\text { learning process. }\end{array}$ & $\begin{array}{l}\text { The teacher and students' } \\
\text { activity in the classroom } \\
\text { before, during, and after } \\
\text { viewing the film. }\end{array}$ & $R Q-1$ \\
\hline $\begin{array}{l}\text { Words, phrases, } \\
\text { terms and written } \\
\text { responses or } \\
\text { statements in the } \\
\text { journal writing. }\end{array}$ & $\begin{array}{l}\text { Students' written responses } \\
\text { through composition with the } \\
\text { guided questions after } \\
\text { viewing the film. From the } \\
\text { film, Students' composition } \\
\text { then will be analyzed. }\end{array}$ & $\mathrm{RQ}-2$ \\
\hline
\end{tabular}

\subsection{Data Collection Techniques}

In the study, documentation, observation, and field notes were the data collection. The followings were the techniques explained:

\subsubsection{Observation}

The researcher observed the teacher's activities before, during, and after the students viewed the film. some notes were taken as the field notes. These were to avoid missing information when they were being analyzed.

\subsubsection{Documentation}

The documents used in the study were ICT media (film), the photos, the observation sheets, and journals of writing. The students were given a selected film to view it. Students then wrote some utterances and thoughts as their journals writing. The researcher classified and did coding on the similar answers to focus on the teacher's techniques and aspects of intercultural awareness the students developed from the film.

\subsection{Data Analysis Techniques}

In accordance with (Ary et al., 2010), there were some steps to the analysis: familiarizing and organizing; coding and reducing; and interpreting and representing.

\subsubsection{Familiarizing and Organizing}

To familiar with the data, the notes and transcripts were read and reread them. The teacher's activities were observed, and taken notes. While the participants' comments were put in the field notes and some were coded. The observation sheets were provided. Words in sentences were transcribed. There could be found words or phrases which grammatically error while transcribing, were suggested not to change them (Ary et al., 2010). The organized-files were taken from the guided-questions answered by the participants. The photocopies were also provided. The back-up copies were kept from the original data.

\subsubsection{Coding and Reducing}

Coding was used to elicit the concepts from the data, which was still raw. Ary et al., (2010) suggested to look for units of words, phrases, sentences, subject's ways of thinking, behavior patterns, and events which were considered to be necessary. The additional information was labeled with codes. The coding was used for analyzing the CCC for knowing aspects of ICA from the students' written responses from the film. The same responses were discarded.

\subsubsection{Interpreting and Representing}

In the study, the data and the background knowledge were interpreted in the story description and explanation. The selected film which represented the analysis was Freedom Writers Diary.

\subsection{Findings}

\subsubsection{The Teacher's Technique of Using Film in Teaching to Develop Students' ICA}

In the study, the researcher conducted the observation on March- April 2019. The observations were the teacher activities using film as a teaching and learning process in the EFL classroom. The teacher activities here were all the teacher' actions in the EFL classroom, which consisted of the action in determining her own teaching method, and objectives in order to accomplish her lesson. Therefore, the researcher made notes that there were three activities in each meeting; the pre-viewing, during viewing, and post-viewing the film. In accordance with the data observation, the researcher found the three activities which were shown by the teacher, could be categorized using QAR strategies of teaching. Those could be seen from the reading provided papers with the guided questions given to the students during teaching and learning EFL. The QAR techniques consisted of four categories. They were known as QAR taxonomy. The categories are: "Right There," "Think and Search," "Own Your Own," and "Author and You." See the following Figure 1. 2, and 3. 


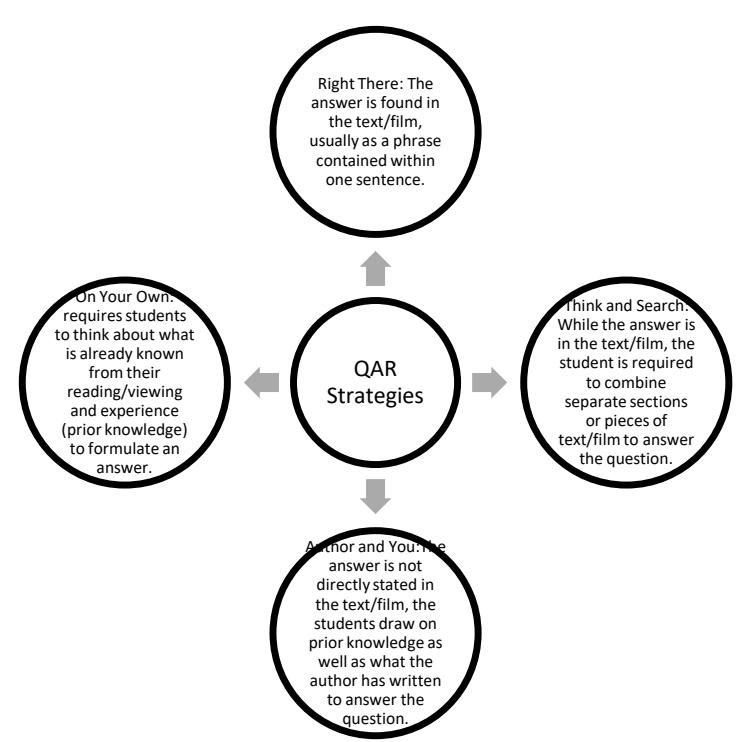

Source:http://wcpssact.pbworks.com/w/file/fetch/64608255/QAR.pdf

As viewing film did not mean to the only process of seeing, reading 'film' was to work through the activities as written that was observed using QAR strategies. The following was a table of research results related to teacher strategies using QAR strategies. See table 2.

Table 2. Using QAR to Frame Questioning Within the Viewing Cycles

\begin{tabular}{|c|c|c|c|c|}
\hline \multicolumn{5}{|c|}{ Using QAR to Frame Questioning Within the Reading/Viewing Cycles } \\
\hline $\begin{array}{l}\text { Reading/Niewing } \\
\text { Cycles }\end{array}$ & Techniques & $\begin{array}{c}\text { QAR } \\
\text { Strategies }\end{array}$ & Questions & $\begin{array}{l}\text { Teacher's } \\
\text { Objectives }\end{array}$ \\
\hline $\begin{array}{l}\text { Before Viewing } \\
\text { the Film }\end{array}$ & $\begin{array}{l}\text { By } \\
\text { visualizing to } \\
\text { the } \\
\text { information } \\
\text { to students' } \\
\text { own } \\
\text { experience }\end{array}$ & $\begin{array}{l}\text { Author } \\
\text { and You }\end{array}$ & $\begin{array}{l}\text { Do you } \\
\text { believe that } \\
\text { if you have } \\
\text { problems, } \\
\text { there will be } \\
\text { the ways } \\
\text { out? Why is } \\
\text { it so? }\end{array}$ & $\begin{array}{l}\text { To relate the } \\
\text { film to } \\
\text { students } \\
\text { before } \\
\text { viewing it; } \\
\text { their } \\
\text { everyday } \\
\text { lives. The } \\
\text { students } \\
\text { draw on } \\
\text { prior } \\
\text { knowledge } \\
\text { and what the } \\
\text { film will } \\
\text { show. }\end{array}$ \\
\hline & $\begin{array}{l}\text { By recalling } \\
\text { students' } \\
\text { past } \\
\text { experiences }\end{array}$ & $\begin{array}{l}\text { On Your } \\
\text { Own }\end{array}$ & $\begin{array}{l}\text { Have you } \\
\text { experienced } \\
\text { racism? If } \\
\text { yes, how did } \\
\text { you feel and } \\
\text { or react? }\end{array}$ & $\begin{array}{l}\text { To attract } \\
\text { students' } \\
\text { attention } \\
\text { before } \\
\text { viewing the } \\
\text { film. This is } \\
\text { also to arise } \\
\text { their interest } \\
\text { in knowing }\end{array}$ \\
\hline
\end{tabular}

\begin{tabular}{|c|c|c|c|c|}
\hline & & & & $\begin{array}{l}\text { more about } \\
\text { the film, } \\
\text { which will be } \\
\text { showed. }\end{array}$ \\
\hline & $\begin{array}{l}\text { By clarifying } \\
\text { to students' } \\
\text { behavior } \\
\text { towards } \\
\text { different } \\
\text { cultures from } \\
\text { their own }\end{array}$ & $\begin{array}{l}\text { Author } \\
\text { and You }\end{array}$ & $\begin{array}{l}\text { How do you } \\
\text { explain the } \\
\text { cultural } \\
\text { diversity? }\end{array}$ & $\begin{array}{l}\text { to find out } \\
\text { students' } \\
\text { understandin } \\
\mathrm{g} \text { of the } \\
\text { importance } \\
\text { of tolerance } \\
\text { in cultural } \\
\text { diversity. }\end{array}$ \\
\hline $\begin{array}{l}\text { During Viewing } \\
\text { the Film }\end{array}$ & $\begin{array}{l}\text { By locating } \\
\text { the } \\
\text { information } \\
\text { from the film }\end{array}$ & $\begin{array}{l}\text { Right } \\
\text { There }\end{array}$ & $\begin{array}{l}\text { How did the } \\
\text { problem } \\
\text { come? Why } \\
\text { did Ms. Erin } \\
\text { Gruwell } \\
\text { relate it to } \\
\text { holocaust to } \\
\text { solve her } \\
\text { problem in } \\
\text { her } \\
\text { classroom? }\end{array}$ & $\begin{array}{l}\text { To help the } \\
\text { students to } \\
\text { answer the } \\
\text { explicit } \\
\text { question } \\
\text { while } \\
\text { viewing the } \\
\text { film }\end{array}$ \\
\hline $\begin{array}{l}\text { After Viewing the } \\
\text { Film }\end{array}$ & $\begin{array}{l}\text { By imagining } \\
\text { to the } \\
\text { position of } \\
\text { the } \\
\text { characters in } \\
\text { the film }\end{array}$ & $\begin{array}{l}\text { Own Your } \\
\text { Own }\end{array}$ & $\begin{array}{l}\text { If you are in } \\
\text { the position } \\
\text { of Mrs. Erin } \\
\text { Gruwell, } \\
\text { what will } \\
\text { you do? } \\
\text { Why? }\end{array}$ & $\begin{array}{l}\text { To make } \\
\text { them } \\
\text { understand } \\
\text { that they } \\
\text { engage with } \\
\text { the teacher } \\
\text { and } \\
\text { classmates } \\
\text { around } \\
\text { them. }\end{array}$ \\
\hline & & & $\begin{array}{l}\text { If you are in } \\
\text { the position } \\
\text { of the } \\
\text { students in } \\
\text { her } \\
\text { classroom, } \\
\text { what will } \\
\text { you do? }\end{array}$ & $\begin{array}{l}\text { To make } \\
\text { them } \\
\text { understand } \\
\text { that they } \\
\text { engage with } \\
\text { the teacher, } \\
\text { classmates, } \\
\text { and people } \\
\text { around them }\end{array}$ \\
\hline & $\begin{array}{l}\text { By } \\
\text { summarizing } \\
\text { the film to } \\
\text { the positive } \\
\text { and negative } \\
\text { sides }\end{array}$ & $\begin{array}{l}\text { Think and } \\
\text { Search }\end{array}$ & $\begin{array}{l}\text { From the } \\
\text { film, what } \\
\text { can you tell } \\
\text { about the } \\
\text { positive and } \\
\text { negative } \\
\text { things from } \\
\text { it? }\end{array}$ & $\begin{array}{l}\text { To add } \\
\text { students' } \\
\text { knowledge } \\
\text { on the } \\
\text { positive } \\
\text { things and } \\
\text { make aware } \\
\text { of the culture } \\
\text { which brings } \\
\text { the negative } \\
\text { things }\end{array}$ \\
\hline & \multicolumn{4}{|c|}{ Showing film fragments/scenes } \\
\hline
\end{tabular}

Here were the six techniques the teacher used to explain table 2 . 


\section{By visualizing to the information to students' own experience}

The students answered the guided questions on the provided papers. This cycle could be found in the pre-viewing stage. This stage could be seen in prior by the teacher first asking their prediction whether they believe or not if they had problems, there would be the ways out. The researcher observed the teacher relating the film to students before viewing it; their everyday lives. Students wrote the reasons too.

\section{By recalling students' past experiences}

Another question was that the teacher asked whether students had ever experienced a similar event in the film by writing it. In one of the papers, two students had ever his/her self- experienced and his/her classmate's experience due to racism. As a matter of fact, most of the students undergo their everyday lives without racism. Yet, there was a little incident involving bullying. The participants confirmed their experience in getting bullied and racist. That indicated the awareness of bullying and racism in the school environment even though there were only two from thirty- six students who experienced those matters.

\section{By clarifying to students' behavior towards different cultures from their own}

The observation continued with the teacher gave the next question. It was "what" the students behave on behalf to the other cultures which were different from theirs and "how" they explained the cultural diversity. Here, the question was used to find out students' understanding of the importance of tolerance in cultural diversity. This was meant that the teacher wanted to find out students' understanding of the importance of tolerance in cultural diversity.

\section{By locating the information from the film}

It was still in the first meeting. The stage was seen in the 'during viewing activity.' This stage took for about thirty-five minutes. The teacher asked the students how the problem came and Why Ms. Erin Gruwell related it to holocaust to solve her problem in her classroom. Students worked independently to answer the questions. While the students were writing their responses, the researcher noted that the teacher moved around actively. The researcher also noted that the teacher sometimes looked at the students' activity while moving around. Indeed, she answered whether there was a question from them. She answered the question in front of the students in order, all of them knew about their classmates' questions. She attempted that there was no similar question. This activity continued until the end of the lesson.

\section{By imagining to the position of the characters in the film}

The next observation was conducted on the second meeting, March 13, 2019. There were two actions given. The first action was continuing to answer the guiding question, and the second action was generally dominated by the students' activity to response the film fragments or scenes given by the teacher.

In continuing to write their answers, the first action question provided two questions. The first question was about what they would do if they were in the position of Ms. Erin Gruwell, the teacher, and as her students with the reasons. This part was Imagining as the teacher in a chaos classroom. On the second action, the observation was conducted on March 20,2019. The teacher gave the film fragments or scenes to trigger the students to find the thematic issues raised by the film. In thematic issues, the researcher observed that the teacher stopped the film. She gave further activities after watching the film. She motivated the students to remember the events that happened in the film. The researcher noted that the teacher showed certain scenes in Freedom Writers Diary to review, clarify, and/or discuss major scenes from the film. She asked the students what they thought about the scenes and should or should not to do in the film.

\section{By summarizing the film to the positive and negative sides}

Here, the teacher gave the question about what students could tell about the positive and negative things from the film. There were eight positive sides found: respect to each other, becoming-an open-minded person, learning to solve the problem, awareness of bullying, initiating to change, understanding equality in education, caring to others, and being optimistic. Meanwhile, for the negative things: the participants showed their awareness of negative stereotypes from other cultures.

\subsubsection{The Students Aspects of ICA from the Film}

The following was the provided table to convey students' aspects of ICA from CCC using film in the EFL classroom. See table 3.

Table 3. Students' Aspects of ICA from CCC

\begin{tabular}{|c|c|c|}
\hline $\mathrm{CCC}$ & Students & Aspects of ICA \\
\hline \multirow{10}{*}{$\begin{array}{lr}\text { Social } & \text { Identity } \\
\text { and } & \text { Social } \\
\text { Group } & \end{array}$} & S1 & Equality in education \\
\hline & S12 & Being polite \\
\hline & S23 & Initiating to change \\
\hline & S4 & No racism \\
\hline & S5 & Respect for others \\
\hline & S16 & No violence \\
\hline & S7 & The importance of family support \\
\hline & S28 & Showing an openness \\
\hline & S29 & The awareness of bullying \\
\hline & S10 & Attempting to overcome the problems \\
\hline
\end{tabular}




\begin{tabular}{|c|c|c|}
\hline $\begin{array}{l}\text { Beliefs and } \\
\text { Behavior }\end{array}$ & $\begin{array}{l}\text { S26 } \\
\text { S36 }\end{array}$ & $\begin{array}{l}\text { The awareness of the importance of } \\
\text { three sides relationship } \\
\text { (teacher-students-friendships } \\
\text { relationship) } \\
\text { The awareness of the importance } \\
\text { of three sides relationship } \\
\text { (teacher-students-friendships } \\
\text { relationship) } \\
\text { The awareness of being religious } \\
\text { Finding success } \\
\text { Being patient } \\
\text { Being honest } \\
\text { Be optimistic }\end{array}$ \\
\hline $\begin{array}{l}\text { Social and } \\
\text { Political } \\
\text { Institutions }\end{array}$ & S34 & $\begin{array}{l}\text { The awareness of school } \\
\text { improvement as an institution }\end{array}$ \\
\hline $\begin{array}{l}\text { National } \\
\text { History }\end{array}$ & S19 & $\begin{array}{l}\text { The awareness of understanding the } \\
\text { problems coming due to the history of } \\
\text { the country }\end{array}$ \\
\hline $\begin{array}{l}\text { National } \\
\text { Geography }\end{array}$ & - & $\begin{array}{l}\text { The awareness of the lack of } \\
\text { geographic knowledge of a country as } \\
\text { a cause of conflict }\end{array}$ \\
\hline $\begin{array}{l}\text { Stereotype and } \\
\text { National } \\
\text { Identity }\end{array}$ & S2 & $\begin{array}{l}\text { The awareness of positive } \\
\text { stereotypes } \\
\text { The awareness of increasing the } \\
\text { cultural diversity understanding }\end{array}$ \\
\hline
\end{tabular}

To explain the table 3.6.2., there were twenty-one aspects of ICA students perceived from the film. Yet, 'respect to others' became the only aspect of ICA that majoring the whole matters to aware other cultures. If the aspect manifested, there would not be the negative things happened. Moreover, it could increase other positive things achieved.

\section{Discussion}

\section{Main Findings of the Study}

The teacher was observed to use QAR techniques of teaching film in the EFL classroom. There are three activities in each meeting; the pre-viewing, during viewing, and post-viewing the film. QAR strategies are often used to develop reading comprehension. And the similarity steps in teaching film were used in QAR strategies. QAR consists of four categories. They are known as QAR taxonomy. The categories are: "Right There," "Think and Search," "Own Your Own," and "Author and You." See figure 1, 2, and 3.

Here, the teacher implemented six steps in teaching film using QAR strategies. The six steps were by visualizing to the information to students' own experience, recalling students' past experiences, clarifying to students' behavior towards different cultures from their own, locating the information from the film, imagining to the position of the characters in the film, and summarizing the film to the positive and negative sides.

There were twenty-one aspects of ICA students perceived from the film. Yet, 'respect to others' became the only aspect of ICA that majoring the whole matters to aware other cultures. If the aspect manifested, there would not be the negative things happened. Moreover, it could increase other positive things achieved.

\section{Relevance to the Previous Studies}

The findings observed in this study mirror those of the previous studies that have examined the effect of relating to the participants' background knowledge, similarly with (Alfred et al. (2003); Kiss \& Weninger (2017)) who stated that the speaker's and the listener's background knowledge as well as their interpretative and reasoning abilities, made them understand utterances to be taken account and carry main focus resource to the language classroom: the experience and prior knowledge as cultural beings.

This study has gone some way the term 'viewing film' with 'reading film,' did not mean to the only process of seeing. Reading 'film' was to work through the activities as written that was observed using QAR strategies. To relate the prior study, Denzin (2004) brought forward to 'reading film, more precisely, was in the relationship between the double registers of what appeared and what could be said or, one might also stated, that it was related to the event of translation between the shared domain between words and images. In addition, Reading Film was a film constructed of visual and discursive intervals, of the gaps in speech, the gaps between signs, the gaps in communication. The finding was in line with Wang (2014), who claimed that the purpose of the film teaching class was to assist students in exploring thematic subtleties in their classroom activities and getting much information of the target language. However, Jacobs (2013) found that sometimes meanings were less clear, and different viewers were possibly to imply the same thing in different ways, based on their own experience and expectancy.

The film had the potential to scaffold historical inquiry using film addressed the concerns of educators who insisted that cinematic representations of the past were used to facilitate analysis and interpretation, rather than for passive content acquisition activities that merely provided a break from the routine of textbook questions and reading (Woelders, 2007). Therefore, the students could understand other cultures which were different from their own. The benefit of this was that the teacher had more interaction with the students in the reading class by using authentic material (Mayasari, Pudjobroto, \& Wahyuni, 2001).

The CCC was correlated to engage with students' aspects of ICA. 'Respect for others' was the main aspect of ICA followed by the whole matters to aware other cultures. To discuss the term 'intercultural,' a previous study stated that it was the implementation of different values to particular situations. 'Intercultural' had affected to the 
changes of people interacting with tolerance and respect for others (Szczepaniak-Kozak \& Romanowski, 2014).

\section{Significance of the Findings}

The six steps which the teacher implemented were identified as the QAR strategy. Here, the researcher noted the similarity of using QAR strategy upon students' reading comprehension in teaching film. In other words, 'viewing film' could be said as the activities in 'reading film.' This technique was very beneficial to conduct to develop students' ICA using film in the EFL classroom. Therefore, QAR strategies using film were recommended for teachers to teach students' ICA in learning a foreign language, including English classroom, especially for high school students in Indonesia, was perfect for exploring ICC. Considering high school EFL learners, it was important that they were aware of cultural differences. In this sense, the ability to understand other cultural perspectives and accept cultural relativism was necessary to reach the aspects of ICA categorically.

\section{The Limitation of the Findings}

First, the limitation of the finding which was not taken account by the teacher was the limited time in teaching. This aimed at maximizing their focusing on the subject. Second, the researcher expected from thirty-six students, more than fifteen students could be investigated with long answers. Yet, there were only fourteen students indicated ready for sharing their ideas.

\section{CONCLUSION}

In conclusion, to answer the first research question, there are four categories in the techniques of intercultural awareness developed through film. The teacher tends to apply the QAR strategies as well as it aims at improving students' reading comprehension through slides before, during and after watching the film. The QAR technique consists of four categories: "On Your Own," "Author and You," "Right There," and "Think and Search." The teacher implemented six steps in teaching film using QAR strategies. The six steps were by visualizing to the information to students' own experience, recalling students' past experiences, clarifying to students' behavior towards different cultures from their own, locating the information from the film, imagining to the position of the characters in the film, and summarizing the film to the positive and negative sides.

The aspects of students' ICA were summarized into twenty-one aspects of ICA whether from CCC or politeness in socio-pragmatics perspectives. Though, 'Respect to others' was the key of the all aspects of ICA. Moreover, the intercultural awareness was a context-bounded in which place, situation, power, and local value influence students' respond toward some movie scenes. Thus, in deciding polite or impolite depends on the age, race, or rank factors, or whether communicants are relatives, friends, or of the same or different social status. In other words, there are some factors that should be considered in determining polite or impolite behavior.

\section{Suggestion}

For the researcher, it was well-suggested to do further research about film for intercultural study deeper. Another suggestion was for the teacher. It was imperative to teach culture alongside language teaching, especially in the globalized world. It was also recommended to immediate attention was important in teacher education programs to prepare teachers to talk about race and diversity in classrooms. It was worrying about disturbing the students' concentration to study in the EFL classroom.

\section{REFERENCES}

Aitken, I. (2012). Lukacsian Film Thoery and Cinema: A Study of Georg Lukacs' Writing on Film. Manchster: Manchester University Press.

Alfred, G., Byram, M., \& Fleming, M. (2003). Intercultural Experience and Education. Clevedon: Multilingual Matters.

Ary, D., Jacobs, L. C., Sorensen, C. K., \& Razavieh, A. (2010). Introduction to Research in Education (8th Editio). Belmont, California: Wadsworth.

Baker, W. (2012). From cultural awareness to intercultural awareness: Culture in ELT. ELT Journal, 66(1), 62-70. https://doi.org/10.1093/elt/ccr017

Baranauskiene, R. (2012). Filologija 2012. Filologija (17), $63,34-44$.

Breeze, R. (2017). Essential Competencies for English-medium University Teaching. 27(October). https://doi.org/10.1007/978-3-319-40956-6

Briam, C. (2010). Outsourced: Using a comedy film to teach intercultural communication. Business Communication Quarterly, 73(4), 383-398. https://doi.org/10.1177/1080569910385567

Bueno, K. A. (2009). Got Film? Is It a Readily Accessible Window to the Target Language and Culture for Your Students? Summer 2009, 318-339.

Byram, M. (1997). Teaching and Assessing Intercultural Communicative Competence. Clevedon: Multilingual Matters.

Byram, M., Gribkova, B., \& Starkey, H. (2002). Developing The Intercultural Dimension in Language Teaching: A Practical Introduction For Teachers. Strasbourgh: Council of Europe.

Byram, M., \& Phipps, A. (2003). Context and Culture in Language Teaching and Learning. In Studies in Second Language Acquisition (Vol. 26). https://doi.org/10.1017/S0272263104290040

Cardon, P. W. (2010). Using Films to Learn About the Nature of Cross-Cultural Stereotypes in Intercultural Business Communication Courses. Business Communication Quarterly, 73(2), 150-165. 
https://doi.org/10.1177/1080569910365724

Cavalli, M., Coste, D., Alexandru, C., \& Van de Ven, P.-H. (2009). Plurilingual and intercultural education as a project. Strasbourgh: Language Policy Divison.

Chao, T. C. (2013). A diary study of university EFL learners' intercultural learning through foreign films. Language, Culture and Curriculum, 26(3), 247-265. https://doi.org/10.1080/07908318.2013.833936

Collins, P. S. (2001). Community Writing: Researching Social Issues Through Composition (London). Lawrence Erlbaum Associates.

Delors, J., Amagi, I., Carneiro, R., Chung, F., Geremek, B., Gorham, W., ... Nanzhao, Z. (1996). The Treasure Within: Report to UNESCO of the International Comission on Education for the Twenty-first Century. Paris.

Denzin, N. (2004). Reading film. A Companion to Cualitative Research, (1972), 237-242.

Fitriani, F., Nur, R. H., Bustamin, B., Ali, S. M., \& Nurisman, N. (2019). Improving Students' Descriptive Text Writing by Using Writing in the Here and Now Strategy at the Tenth Grade Students of Vocational High School. International Journal for Educational and Vocational Studies, 1(6), 632-636.

Galante, A. (2015). Intercultural Communicative Competence in English Language Teaching: Towards Validation of Student Identity. BELT - Brazilian English Language Teaching Journal, 6(1), 29. https://doi.org/10.15448/2178-3640.2015.1.20188

Halliday, M. A. ., \& Hasan, R. (1989). Halliday,M.A.K-1989.pdf (First Edit). New York: York University Libraries.

Hashemi, Z., \& Amerian, M. (2011). the Impact of Journal Writing on the Correct Use of Grammar Among Efl Students of Rafsanjan Vali-E-Asr University. XL(October 2017), 48-59.

Hekmati, N., Ghajar, S. G., \& Navidinia, H. (2018). Movie-generated EFL Writing: Discovering the Act of Writing through Visual Literacy Practices. Internationa; Journal of Language Studies, 12(2), 51-64.

Jacobs, C. P. (2013). Film Theory and Approaches to Criticism, or, What did that Movie Mean? University of North Dakota. Retrieved from http://www.und.edu/instruct/cjacobs/FilmTheory\&An alysis.htm

Jago, C., Shea, R. H., \& Scanlon, L. (2011). Literature \& Composition Reading - Writing - Thinking. Boston: Bedford/St.Martin's.

Kiss, T., \& Weninger, C. (2017). Cultural learning in the EFL classroom: The role of visuals. ELT Journal, 71(2), 186-196. https://doi.org/10.1093/elt/ccw072

Kusumaningputri, R., \& Widodo, H. P. (2018). Promoting Indonesian university students' critical intercultural awareness in tertiary EAL classrooms: The use of digital photograph-mediated intercultural tasks. System, 72, 49-61.

https://doi.org/10.1016/j.system.2017.10.003

Marzuki, M. (2019). Common Mistakes Found in Essay Writing of Chemical Engineering Department First Grade Students in Politeknik Negeri Lhokseumawe. International Journal for Educational and Vocational Studies, 1(6). 591-594

Mallinger, M., \& Rossy, G. (2003). Journal of Management Education. OBTS Teaching Society for Management Educators, 608-624. https://doi.org/10.1177/1052562903252642

Mayasari, A., Pudjobroto, A. H., \& Wahyuni, D. S. (2001). Improving Students' Reading Comprehension Through Question-Answer Relationships. English Education, 2, 43-51.

P. M. Ribeiro, S. (2016). Developing intercultural awareness using digital storytelling. Language and Intercultural Communication, 16(1), 69-82. https://doi.org/10.1080/14708477.2015.1113752

Pegrum, M. (2008). Film, Culture and Identity: Critical Classroom Film, Culture and Identity: Critical Intercultural Literacies for the Language Classroom. (October 2014), 37-41.

https://doi.org/10.1080/14708470802271073

Roell, C. (2010). Intercultural Training with Films. English Teaching Forum, 1-14.

Samovar, L. A., Porter, R. E., Mcdaniel, E. R., \& Roy, C. S. (2012). Communication Between Cultures (8th Editio). Boston: Cengage Learning.

Scollon, R. (2001). Language in Society 21: Intercultural Communication Culture (Second Edi). Oxford, UK: Blackwell Publisher.

Sercu, L. (2005). Foreign Language Teachers and Intercultural Cpmpetence: An International Investigation. Clevedon: Multilingual Matters.

Sturm, J. L. (2012). Using Film in the L2 Classroom: A Graduate Course in Film Pedagogy. XX(X), 1-14. https://doi.org/10.111/j.1944-9720.2012.01187.x.2

Szczepaniak-kozak, A., \& Romanowski, P. (2014). Developing intercultural pragmatic competence in the classroom: Selected theoretical and practical assumptions. In Intercultural Issues in the Era of Globalization. Naukowe: Wydawnictwo Naukowe.

Tanghe, S. (2016). Promoting critical racial awareness in teacher education in Korea: reflections on a racial discrimination simulation activity. Asia Pacific Education Review, 17(2), 203-215. https://doi.org/10.1007/s12564-016-9424-y

Tarp, G. (2017). Influences on intercultural classroom communication: student voices. Pedagogies, 12(2), 219-231.

https://doi.org/10.1080/1554480X.2017.1289845

Truong, L. B., \& Tran, L. T. (2014). Language and 
Intercultural Communication Students ' intercultural development through language learning in Vietnamese tertiary education: a case study on the use of film as an innovative approach. Language and Intercultural Communication, 2(November 2014), 207-225.

https://doi.org/10.1080/14708477.2013.849717

Wang, Y. (2014). Using Films in the Multimedia English Class. English Language Teaching, 2(1), 179-184. https://doi.org/10.5539/elt.v2n1p179

Woelders, A. (2007). It Makes You Think More When You Watch Things ": Scaffolding for Historical Inquiry Using Film in the Middle School Classroom. The Social Studies, 4(August), 145-152. 